\title{
Ocean Acidification Experiments in Large-Scale Mesocosms Reveal Similar Dynamics of Dissolved Organic Matter Production and Biotransformation
}

\author{
Maren Zark ${ }^{1 *}$, Nadine K. Broda ${ }^{1}$, Thomas Hornick ${ }^{2}$, Hans-Peter Grossart ${ }^{2,3}$, Ulf Riebesell ${ }^{4}$ \\ and Thorsten Dittmar ${ }^{1}$ \\ ${ }^{1}$ Research Group for Marine Geochemistry (ICBM-MPI Bridging Group), Institute for Chemistry and Biology of the Marine \\ Environment, Carl von Ossietzky University of Oldenburg, Oldenburg, Germany, ${ }^{2}$ Experimental Limnology, Leibniz-Institute of \\ Freshwater Ecology and Inland Fisheries, Stechlin, Germany, ${ }^{3}$ Institute for Biochemistry and Biology, University of Potsdam, \\ Potsdam, Germany, ${ }^{4}$ GEOMAR Helmholtz Centre for Ocean Research Kiel, Kiel, Germany
}

\section{OPEN ACCESS}

Edited by: Christel Hassler,

Université de Genève, Switzerland

Reviewed by:

Wei-dong Zhai,

Shandong University, China

Elvira Pulido-Villena,

Mediterranean Institute of Oceanography - MIO, France

*Correspondence:

Maren Zark

maren.zark@uni-oldenburg.de

Specialty section: This article was submitted to

Marine Biogeochemistry,

a section of the journal

Frontiers in Marine Science

Received: 22 March 2017

Accepted: 07 August 2017

Published: 05 September 2017

Citation:

Zark M, Broda NK, Hornick T,

Grossart H-P, Riebesell U and

Dittmar T (2017) Ocean Acidification

Experiments in Large-Scale Mesocosms Reveal Similar Dynamics

of Dissolved Organic Matter

Production and Biotransformation.

Front. Mar. Sci. 4:271.

doi: 10.3389/fmars.2017.00271
Dissolved organic matter (DOM) represents a major reservoir of carbon in the oceans. Environmental stressors such as ocean acidification (OA) potentially affect DOM production and degradation processes, e.g., phytoplankton exudation or microbial uptake and biotransformation of molecules. Resulting changes in carbon storage capacity of the ocean, thus, may cause feedbacks on the global carbon cycle. Previous experiments studying OA effects on the DOM pool under natural conditions, however, were mostly conducted in temperate and coastal eutrophic areas. Here, we report on OA effects on the existing and newly produced DOM pool during an experiment in the subtropical North Atlantic Ocean at the Canary Islands during an (1) oligotrophic phase and (2) after simulated deep water upwelling. The last is a frequently occurring event in this region controlling nutrient and phytoplankton dynamics. We manipulated nine large-scale mesocosms with a gradient of $\mathrm{pCO}_{2}$ ranging from $\sim 350$ up to $\sim 1,030 \mu \mathrm{atm}$ and monitored the DOM molecular composition using ultrahigh-resolution mass spectrometry via Fourier-transform ion cyclotron resonance mass spectrometry (FT-ICR-MS). An increase of $37 \mu \mathrm{mol} \mathrm{L} \mathrm{L}^{-1}$ DOC was observed in all mesocosms during a phytoplankton bloom induced by simulated upwelling. Indications for enhanced DOC accumulation under elevated $\mathrm{CO}_{2}$ became apparent during a phase of nutrient recycling toward the end of the experiment. The production of DOM was reflected in changes of the molecular DOM composition. Out of the 7,212 molecular formulae, which were detected throughout the experiment, 50\% correlated significantly in mass spectrometric signal intensity with cumulative bacterial protein production (BPP) and are likely a product of microbial transformation. However, no differences in the produced compounds were found with respect to $\mathrm{CO}_{2}$ levels. Comparing the results of this experiment with a comparable OA experiment in the Swedish Gullmar Fjord, reveals similar succession patterns for individual compound pools during a phytoplankton bloom 
and subsequent accumulation of these compounds were observed. The similar behavior of DOM production and biotransformation during and following a phytoplankton bloom irrespective of plankton community composition and $\mathrm{CO}_{2}$ treatment provides novel insights into general dynamics of the marine DOM pool.

Keywords: dissolved organic matter, ocean acidification, ultrahigh resolution mass spectrometry, FT-ICR-MS, molecular composition, subtropical North Atlantic, mesocosm experiment

\section{INTRODUCTION}

The global ocean currently takes up about $25 \%$ of all annually emitted anthropogenic $\mathrm{CO}_{2}$ (Le Queré et al., 2013). Once dissolved in seawater, most of the $\mathrm{CO}_{2}$ is transported into deep waters via thermohaline circulation and the biological pump. A smaller fraction of the $\mathrm{CO}_{2}$, however, forms carbonic acid and causes a decline in $\mathrm{pH}$ in the surface ocean (Zhai and Zhao, 2016). This process is commonly referred to as ocean acidification (OA). Under a business-asusual climate scenario, surface ocean $\mathrm{pH}$ could be reduced by 0.4 units until the end of the century compared to preindustrial levels (IPCC, 2014). OA may impact physiology of marine organisms, structure of phytoplankton communities, and the biogeochemical cycling of elements (Riebesell et al., 2007, 2017; Kroeker et al., 2010; Dutkiewicz et al., 2015).

One important pool in the marine carbon cycle that may be affected by OA is dissolved organic matter (DOM). It holds a similar amount of carbon as all living biomass on Earth (Hedges, 1992). This huge carbon pool is mainly produced by marine primary producers and consumed and biotransformed within the microbial loop at the bottom of the marine food web (Azam et al., 1983; Carlson et al., 2007). A stimulation of marine primary production by OA (Riebesell, 2000; Engel et al., 2013; Eberlein et al., 2017) may consequently lead to enhanced production of DOM and subsequently stimulate microbial mineralization (Grossart et al., 2006; Piontek et al., 2010). Thus, concurrent OA-induced changes in degradation and transformation processes affect DOM quantity and quality and have the potential to impact the biogeochemical carbon cycle (Moran et al., 2016).

The surface ocean contains a large fraction of labile DOM that is readily respired to $\mathrm{CO}_{2}$. Only a smaller fraction of marine primary production is channeled into more recalcitrant DOM fractions (Hansell et al., 2012). This recalcitrant DOM is of importance in terms of oceanic carbon storage and may be altered in a more acidified ocean. So far, OA experiments monitored mainly bulk dissolved organic carbon (DOC) concentrations by neglecting the quality of DOM pools. Thereby, the effect of elevated $\mathrm{CO}_{2}$ on bulk DOC concentrations in seawater was reported to be positive in large-scale mesocosm and incubation experiments (e.g., Czerny et al., 2013; Engel et al., 2013). However, other studies report no or even negative effects (Yoshimura et al., 2010; Engel et al., 2014; MacGilchrist et al., 2014; Zark et al., 2015a). In contrast, monitoring the molecular DOM composition via FT-ICR-MS may reveal changes in the quality of the accumulating DOM fraction. FT-ICR-MS is to date the only available analytical technique that holds the power to resolve the molecular masses of more than $60 \%$ of intact molecules in DOM (Mopper et al., 2007; Dittmar et al., 2008). In a previous long-term mesocosm experiment in the Swedish Gullmar Fjord, OA effects on DOM molecular composition were analyzed for the first time in an ultrahigh resolution by using Fourier-transform ion cyclotron resonance mass spectrometry (FT-ICR-MS). This study revealed no effects of elevated $p \mathrm{CO}_{2}$ as projected for the end of this century on the DOM pool size and molecular composition in this eutrophic temperate system (Zark et al., 2015a). To what extent these findings can be extrapolated to other regions, in particular less eutrophic open waters, is presently unknown. Microbial communities in surface waters of oligotrophic areas experience less variability in $\mathrm{pH}$ than in coastal regions (Hofmann et al., 2011) and are hence less adapted to rapid changes in pH (Salisbury et al., 2008; Joint et al., 2011).

In this study, we tested the effects of $\mathrm{OA}$ on the DOM molecular composition in a subtropical system under oligotrophic conditions and in response to simulated upwelling of nutrient-rich deep water. Oligotrophic areas comprise $\sim 30 \%$ of the global oceanic primary production and changes in DOM accumulation in these areas may have significant impacts on the marine carbon cycle (Longhurst et al., 1995). So far, effects of OA in oligotrophic environments remain largely unknown, since most community-level field experiments were conducted under nutrient replete conditions. To bridge this knowledge gap, we performed a large-scale pelagic mesocosm experiment in the subtropical North Atlantic Ocean off the coast of Gran Canaria. This area is part of the Canary Current system, where upwelling of nutrient-rich deep water seasonally induces phytoplankton blooms (Aristeguí et al., 2009) and controls net production of DOC by input of additional nutrients (Romera-Castillo et al., 2016). Nine sea-going mesocosm systems were deployed, two of them served as controls with ambient $p \mathrm{CO}_{2}$ levels and seven others were artificially enriched with $\mathrm{CO}_{2}$. A gradient design with a range of $p \mathrm{CO}_{2}$ levels from $\sim 350$ to $\sim 1,030 \mu$ atm was chosen to test for the presence of a threshold for detecting $p \mathrm{CO}_{2}$ induced effects. After $\sim 3$ weeks, we added $\sim 8,000$ L of nutrient-rich deepsea water to each mesocosm to simulate an upwelling event and monitored responses for another $\sim 5$ weeks (Taucher et al., 2017). DOC and dissolved organic nitrogen (DON) concentrations were measured as well as the changes in molecular DOM composition via FT-ICR-MS over the course of the oligotrophic phase and an upwelling-induced phytoplankton bloom. Specifically, we aimed for DOM that accumulates on timescales of weeks or longer, because it represents the non-labile fraction of DOM and is most important for carbon storage. We hypothesize that the effect of increased $p \mathrm{CO}_{2}$ on the amount of primary production channeled 
via the microbial loop into the more recalcitrant DOM pool is more pronounced under oligotrophic compared to eutrophic conditions.

\section{MATERIALS AND METHODS}

\section{Experimental Set-Up}

The mesocosm experiment was performed from September to November 2014 at the Plataforma Oceánica de Canarias (PLOCAN) on Gran Canaria, Spain. A technical description of the Kiel Off-Shore Mesocosms for Ocean Simulations (KOSMOS) facility and the experimental design is given in Riebesell et al. (2013) and Schulz et al. (2013). In brief, nine cylindrical mesocosms of $\sim 35 \mathrm{~m}^{3}$ volume were deployed in the Bay of Gando (Figure 1) and filled at the same time with seawater from the Atlantic. The mesocosms were manipulated with $\mathrm{CO}_{2}$ to reach average $p \mathrm{CO}_{2}$ levels of 450 (M5), 560 (M3), 670 (M7), 720 (M4), 890 (M2), and 1,030 $\mathrm{atm}$ (M8) between day 1 and day 55 (rounded values). The remaining two mesocosms were used as controls at ambient $p \mathrm{CO}_{2}$-values of 350 (M9) to $370 \mu \mathrm{atm}$ (M1). Initial manipulations with $\mathrm{CO}_{2}$ were done by stepwise addition of $\mathrm{CO}_{2}$ saturated seawater (days $0,2,4$, and 6). All mesocosms were open to the atmosphere and $\mathrm{CO}_{2}$ enriched water had to be added at several time points to keep the $p \mathrm{CO}_{2}$ level close to the target (days 21 and 38). After $\mathrm{CO}_{2}$ manipulation, the $\mathrm{pH}$ was on average 0.26 units lower in the enriched mesocosms compared to the controls. To simulate a naturally occurring upwelling event we added about $8,000 \mathrm{~L}$ deep-sea water $\left(62 \mu \mathrm{mol} \mathrm{L}{ }^{-1}\right.$ DOC, $17 \mu \mathrm{mol}$ $\mathrm{L}^{-1}$ combined $\mathrm{NO}_{3}^{-}$and $\mathrm{NO}_{2}^{-}$) to each of the mesocosms on day 23. It has to be noted that one of the mesocosms with moderate $p \mathrm{CO}_{2}$ treatment (M6) was damaged on day 26 and had to be excluded from all statistical and graphical analyses. Comprehensive information about experiment design and basic parameters is provided in an overview by Taucher et al. (2017).

\section{Sample Preparation and Bulk Analysis}

Representative samples were collected for both, the mesocosms and the surrounding Atlantic water, every other day from boats between 09:00 a.m. and 12:00 a.m. local time, starting from the day after the mesocosm bags were closed (day-3). We used $5 \mathrm{~L}$ integrating water samplers (IWS, Hydrobios) collecting a representative sample for the upper $13 \mathrm{~m}$ of the water column. Carbonate chemistry parameters such as $\mathrm{pH}$ and $p \mathrm{CO}_{2}$ were calculated from total alkalinity (TA) and dissolved inorganic carbon (DIC) using $\mathrm{CO}_{2}$ SYS (Pierrot et al., 2006) and dissociation constants of Lueker et al. (2000) as described in Taucher et al. (2017). In brief, TA analyses were carried out via potentiometric titration (Metrohm 862 Titrosampler) after Dickson et al. (2003) and DIC concentrations were determined by infrared absorption of $\mathrm{CO}_{2}$ purged from an acidified sample (MARIANDA AIRICA system with LI-COR LI-7000). Concentrations of chlorophyll $a$ (Chl $a$ ) and other phytoplankton pigments were analyzed by high performance liquid chromatography (HPLC). Therefore, samples (500$1,000 \mathrm{~mL}$ ) were collected by filtration onto glass fiber filters ( $\mathrm{GF} / \mathrm{F}$

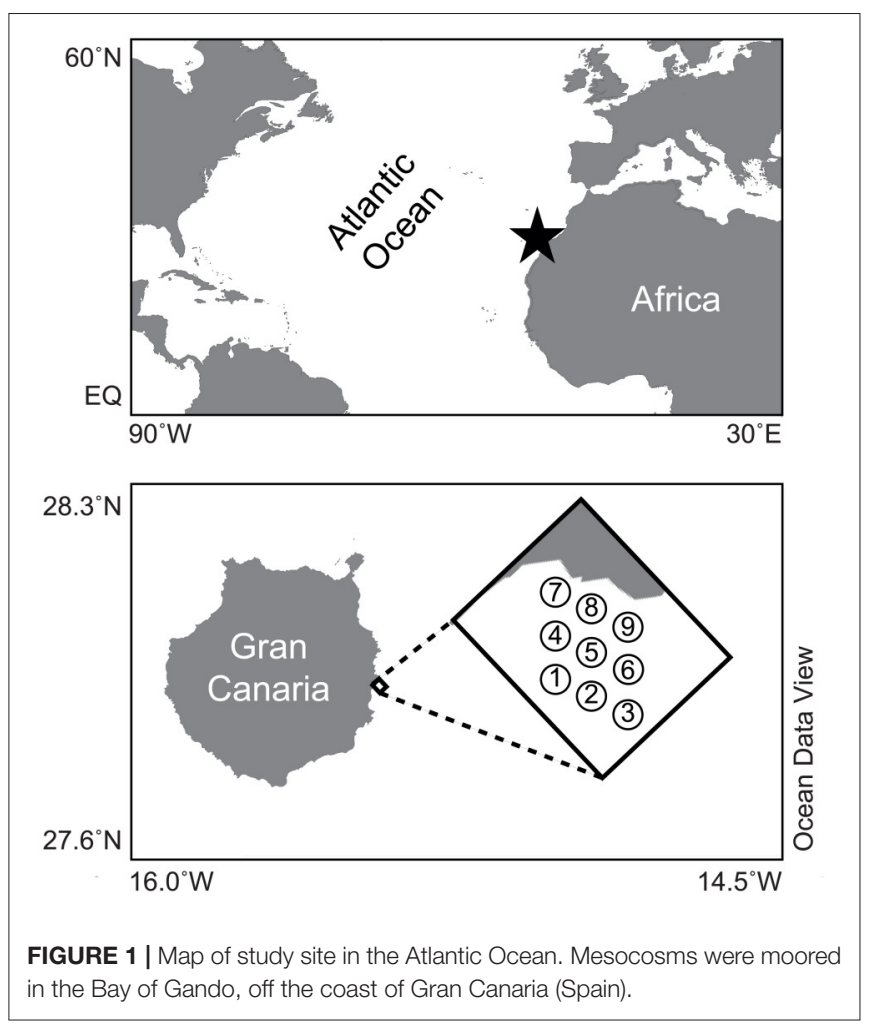

Whatman, nominal pore size of $0.7 \mu \mathrm{m}$ ) and stored in cryovials at $-80^{\circ} \mathrm{C}$. For the HPLC analyses, samples were extracted in acetone $(100 \%)$ in plastic vials by homogenization of the filters using glass beads in a cell mill. After centrifugation $(10 \mathrm{~min}$, $\left.5,200 \mathrm{rpm}, 4^{\circ} \mathrm{C}\right)$ the supernatant was filtered through $0.2 \mu \mathrm{m}$ PTFE filters (VWR International). From this, phytoplankton pigment concentrations were determined using a Thermo Scientific HPLC Ultimate 3000 with Eclipse XDB-C8 3.5u $4.6 \times$ 150 column.

For dissolved organic carbon (DOC) and total dissolved nitrogen (TDN) analysis, samples were collected into prerinsed $250 \mathrm{~mL}$ polycarbonate bottles (Nalgene) in triplicate. The samples were then filtered through a syringe with $0.7 \mu \mathrm{m} \mathrm{GF} / \mathrm{F}$ pre-combusted $\left(400^{\circ} \mathrm{C}, 4 \mathrm{~h}\right)$ glass microfiber filters (Whatman) into pre-combusted $20 \mathrm{~mL}$ glass vials $\left(400^{\circ} \mathrm{C}, 4 \mathrm{~h}\right)$ with acidrinsed Teflon caps (Wheaton). Directly after filtration, we acidified samples with $\mathrm{HCl}$ (25\%, analysis grade, Carl Roth) to $\mathrm{pH}$ 2. The analysis of DOC and TDN concentrations was done via a high-temperature catalytic oxidation method (Qian and Mopper, 1996) using a Shimadzu TOC-VCPH/CPN Total Organic Carbon Analyzer, equipped with ASI V auto sampler and TNM-1 module for the determination of TDN. The accuracy of the measurement was controlled with Florida Strait Water reference material (D.A. Hansell, University of Miami, Florida) for every run. The error for DOC and TDN analysis was on average 4 and 10\%, respectively. Average concentrations were calculated for each mesocosm and time point from triplicates. We calculated dissolved organic nitrogen (DON) concentrations from TDN by subtracting the concentration of all dissolved inorganic nitrogen species (DIN). DIN is the sum of nitrate, 
nitrite and ammonium concentrations that were measured using a segmented flow analyzer (SEAL QuAAtro).

\section{Molecular Characterization}

Samples for molecular DOM characterization were collected from the IWS sampler into $2 \mathrm{~L}$ acid-rinsed polycarbonate bottles (Nalgene). The samples were transported to shore and stored at in situ water temperatures in the dark until processing on the same day. After filtration through $0.7 \mu \mathrm{m}$ GF/F glass microfiber filters (Whatman) using manual vacuum pumps $(<200$ mbar $)$ we acidified samples with $\mathrm{HCl}$ (25\%, analysis grade, Carl Roth) to $\mathrm{pH} 2$. Samples were stored at $4^{\circ} \mathrm{C}$ in the dark until subsequent solid phase extraction (SPE) according to Dittmar et al. (2008). We used a commercially available modified styrene divinyl benzene polymer resin (PPL, $1 \mathrm{~g}$, Agilent). Prior to use, cartridges were soaked in methanol (HPLC grade, Sigma-Aldrich) overnight, and rinsed sequentially with methanol and $0.01 \mathrm{~mol} \mathrm{~L}^{-1} \mathrm{HCl}$ in ultrapure water. After loading the samples onto the cartridges they were rinsed with $0.01 \mathrm{~mol} \mathrm{~L}^{-1} \mathrm{HCl}$ to remove all remaining salts and dried with nitrogen gas (analysis grade, Air Liquide). The extracted DOM was eluted with $6 \mathrm{~mL}$ methanol and stored in pre-combusted glass vials at $20^{\circ} \mathrm{C}$. Extraction efficiencies for this method are typically $>60 \%$ on a carbon basis (Stubbins and Dittmar, 2012; Green et al., 2014). Especially colloidal matter and small ionic compounds may escape extraction and are likely lost from our analytical window. For this study the average extraction efficiency was $34 \pm 4 \%$ across all mesocosms. Despite the relatively low recovery, SPE-DOC concentrations followed the general succession of DOC concentrations and can hence be considered as representative. Procedural blanks were prepared by processing ultrapure water the same way as DOM samples. The detection limit for solid phase extractable DOC (SPE-DOC) was lower than the detection limit for regular DOC samples (Stubbins and Dittmar, 2012) due to concentration by a factor of hundred. SPEDOC concentrations in the resulting blank extracts were slightly above detection limit but did not exceed a concentration level of $12.3 \mu \mathrm{mol} \mathrm{L}-1$.

We used FT-ICR mass spectrometry for molecular characterization of the DOM pool. Thereby, individual compounds can be resolved from the complex mixture and due to the high mass accuracy, molecular formulae can be assigned. Molecular formulae may be grouped into categories according to indices derived from elemental composition ("Aliphatics" $\mathrm{H} / \mathrm{C} \geq 1.5$, "CRAM O-poor" $\mathrm{H} / \mathrm{C}<1.5 \& \mathrm{AI}_{\bmod } \leq 0.5 \& \mathrm{O} / \mathrm{C}$ $\leq$ 5, "CRAM O-rich" H/C $<1.5 \& \mathrm{AI}_{\bmod } \leq 0.5 \& \mathrm{O} / \mathrm{C}>0.5$, "Polyphenols" $0.5<\mathrm{AI}_{\text {mod }} \leq 0.66$, "Polycyclic aromatics" $\mathrm{AI}_{\text {mod }}$ $>0.66$ ) (Koch and Dittmar, 2006; Riedel et al., 2016). This is not meant to be an unambiguous identification of molecular structures.

Mass spectra were obtained on a 15 Tesla Solarix FT-ICR-MS system (Bruker Daltonics) equipped with an electrospray ionization source (ESI, Bruker Apollo II) applied in negative ionization mode. Methanol extracts were diluted with ultrapure water and methanol to give a final concentration of $15 \mathrm{mg} \mathrm{C} \mathrm{L}^{-1}$ in a 1:1 mixture (v/v) of methanol (HPLC grade, Sigma-Aldrich) and ultra-pure water. For each measurement we accumulated
500 scans in the mass window of 150-2,000 Da. We calibrated spectra internally with a reference mass list using the Bruker Daltonics Data Analysis software package. The mass error of the calibration was $<0.06 \mathrm{ppm}$ for all samples. To remove noise a method detection limit following the guidelines of Riedel and Dittmar (2014) was applied. Compounds detected in procedural blanks were removed. We further found a group of likely contaminants $(n=50)$, which continuously increased in all mesocosms. These compounds were excluded from statistical analysis, as some of them correspond to known constituents of detergents. During previous mesocosm experiments using the identical setup, however, no such contamination could be observed (Zark et al., 2015a).

All 89 samples from a total of 10 time points (79 samples from mesocosms and 10 from the Atlantic) were analyzed via FT-ICR-MS in random order. To test the reproducibility and stability of the FT-ICR-MS analysis, we analyzed DOM extract of North Equatorial Pacific Intermediate Water (NEqPIW) twice per day (Green et al., 2014). MATLAB routines developed by our working group were applied for molecular formula assignment and further data processing. All molecules were detected as singly-charged ions and molecular formulae were assigned based on the criteria by Koch et al. (2007) and Rossel et al. (2013), under consideration of the elements $\mathrm{C}, \mathrm{H}, \mathrm{O}, \mathrm{N}, \mathrm{S}$, and $\mathrm{P}$.

\section{Bacterial Protein Production}

Rates of bacterial protein production (BPP) were determined by incorporation of ${ }^{14}$ C-leucine (Simon and Azam, 1989) modified after Grossart et al. (2006) and Allgaier et al. (2008). Triplicates and a formol-killed control were incubated in situ with ${ }^{14} \mathrm{C}$-Leu (318 $\mathrm{mCi} \mathrm{mmol}{ }^{-1}$; Hartmann Analytic) at a concentration, which ensured saturation of the bacterial uptake systems. Incubation was performed for $1 \mathrm{~h}$ in dark at in situ temperature and gentle moving of closed containers in a water bath to prevent settling of particles. After fixation with $2 \%$ formalin, samples were filtered onto $5.0 \mu \mathrm{m}$ nitrocellulose filters (Sartorius AG) for the particle associated bacteria fraction and extracted with ice-cold 5\% trichloracetic acid (TCA) for $5 \mathrm{~min}$. Thereafter, filters were rinsed twice with icecold 5\% TCA, once with ethanol $(50 \% \mathrm{v} / \mathrm{v})$ and mixed with liquid scintillation cocktail (Ultima Gold ${ }^{\mathrm{TM}}$, Perkin Elmer). For the free-living bacteria the filtrate was filtered on $0.2 \mu \mathrm{m}$ nitrocellulose filters (Sartorius) and processed in the same way. The incorporated leucine was measured as disintegrations per minute $(\mathrm{dpm})$ on a liquid scintillation analyzer (TriCarb 2810 TR, Perkin Elmer). The sum of incorporated ${ }^{14} \mathrm{C}$-leucine of both size-fractions was converted into BPP by using an intracellular isotope dilution factor of 2 (Kirchman, 1993). A factor of 0.86 was used to convert the produced protein in carbon (Simon and Azam, 1989). Standard deviation of triplicate measurements was usually $<15 \%$. Cumulative BPP was determined by summing up the average rates per day of experiment.

\section{Statistical Analysis of FT-ICR-MS Data}

All statistical analyses were based on normalized peak magnitudes of FT-ICR-MS signals. Variations in the molecular 
DOM composition were characterized by principal components analysis (PCA). Additionally, a Bray-Curtis based distance matrix was calculated. This method from ecology aims at quantification of the dissimilarity of different ecological sites based on the counts of individual species (Bray and Curtis, 1957). In analogy, we calculated the dissimilarity of all mesocosms at each time point throughout the experiment based on normalized peak magnitudes of the individual DOM compounds. The dissimilarity may reach values between 0 (the two mesocosms share all molecular formulae in similar abundances) and 1 (the mesocosms share no molecular formulae). Thereby, a general comparison of the molecular diversity between samples can be obtained. We further calculated Pearson product-moment correlation coefficients $(r)$ for the co-correlation of individual relative signal intensities of each detected molecular formula with cumulative BPP over time (Figure 4C). This statistical approach results in Pearson correlation coefficients $(r)$ for all molecular formulae of each individual mesocosm (Figure 4B). Pearson correlation coefficients can range from -1 (negative linear relationship) to 1 (positive linear relation). We then used the obtained correlation coefficients for a follow-up Pearson correlation between the mesocosm units that aimed at revealing similar temporal dynamics of DOM molecular formulae (Figure 4A). All statistical analyses were performed with the software package R (Version 3.0.2, package "vegan," Oksanen et al., 2013).

\section{RESULTS}

\section{DOC Production after a Phytoplankton Bloom Induced by Artificial Upwelling}

Prior to the addition of $\mathrm{CO}_{2}$, mesocosms showed similar conditions after a short equilibration period (Figures 2A-D). After $\mathrm{CO}_{2}$ addition, $p \mathrm{CO}_{2}$ inside the mesocosms showed temporal fluctuations throughout the experiment due to outgassing and repeated additions of $\mathrm{CO}_{2}$ that were done to readjust the gradient. An overview on the temporal succession of $p \mathrm{CO}_{2}$ in the experiment is provided by Taucher et al. (2017). The temporal succession of phytoplankton biomass was similar for all mesocosms and can be divided into three phases that were driven by different processes. The first phase of the experiment was characterized by oligotrophic conditions (phase I) with stable and low chlorophyll $a$ concentrations (Figure 2A). During this phase, an increase in DOC concentration was observed (Figure 2B) from $80 \pm 5 \mu \mathrm{mol} \mathrm{L}^{-1}$ on day 3 to $112 \pm 5 \mu \mathrm{mol} \mathrm{L}^{-1}$ on day 23 (mean $\pm S D$ ), while BPP remained stable (Figure 2D). A similar trend was not observed for the samples from the Atlantic. Immediately after the start of phase II, with addition of nutrientrich deep water, chlorophyll $a$ rapidly increased in all mesocosms (Figure 2A). A maximum of $3.5 \mu \mathrm{g} \mathrm{L}^{-1}$ was reached on day 28 which is within the range of chlorophyll $a$ ( $\mathrm{Chl} a$ ) maxima in winter months and is typical for the subtropical oligotrophic Atlantic after upwelling events at this time of the year (Neuer

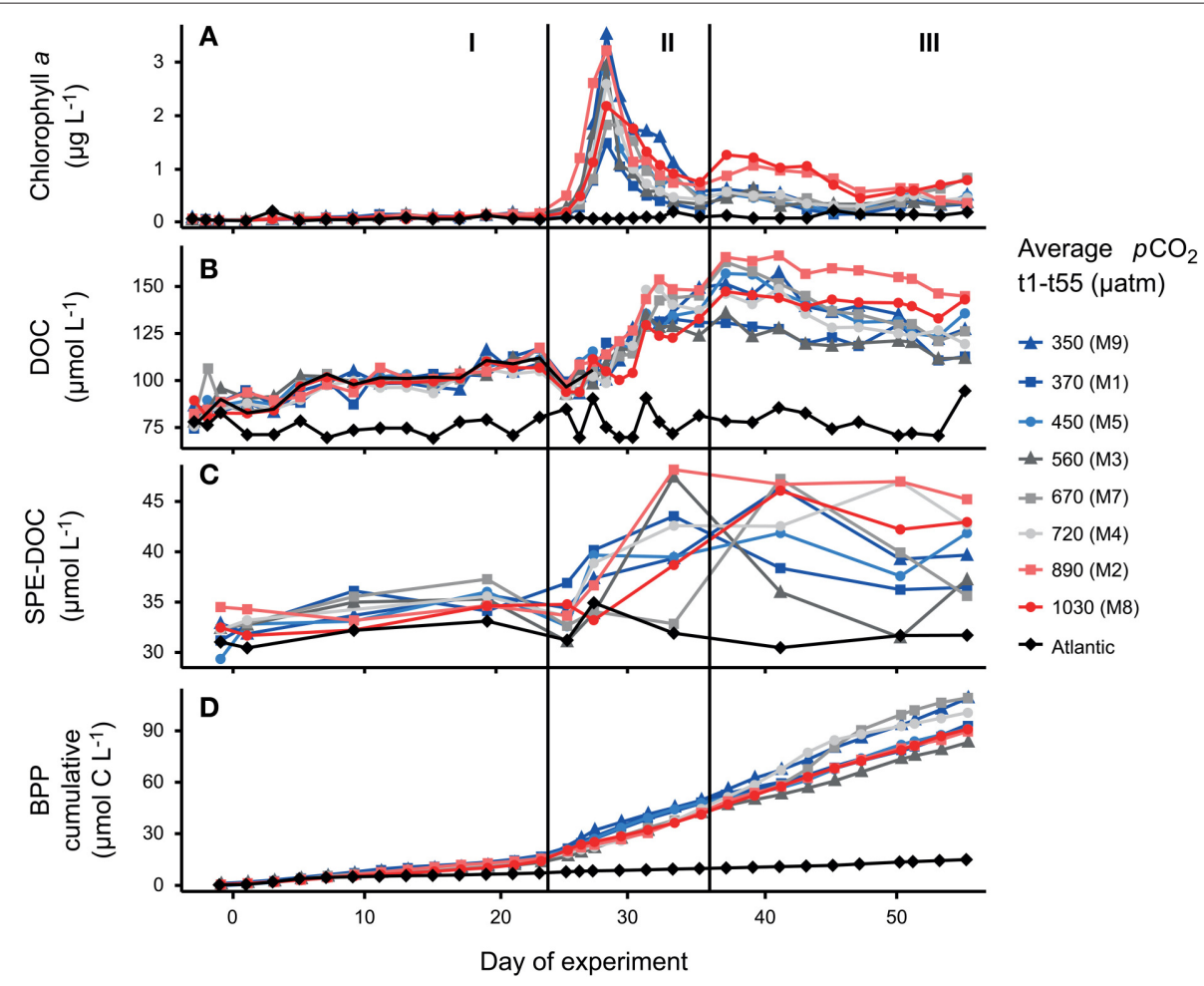

FIGURE 2 | Time series data from the mesocosm units and surrounding Atlantic water. Colors display the average $p \mathrm{CO}_{2}$ value from day 1 to day 55 . Concentration of (A) chlorophyll a, (B) dissolved organic carbon (DOC), (C) SPE-DOC as measure of the solid-phase extractable component in dissolved organic matter, and (D) cumulative bacterial protein production over experiment time. 
et al., 2007). The bloom was dominated by diatoms ( $70 \%$ of Chl $a$ ) as the most abundant group, but also included other groups such as dinoflagellates, prymnesiophytes (Phaeocystis) and cyanobacteria (e.g., Synechococcus) (Taucher et al., 2017). A sharp decrease of DOC from day 23 to day 25 occurred due to dilution by the injected deep water. At the same time, cumulative BPP increased from $41.8 \pm 3.1$ to $54.5 \pm 4.4 \mu \mathrm{mol} \mathrm{C}$ $\mathrm{L}^{-1}$ (Figure 2D). DOC concentrations increased to a maximum of $149 \pm 12 \mu \mathrm{mol} \mathrm{L}^{-1}$ after the decay of the bloom on day 37 (Figure 2B). Inorganic nutrients were again depleted from day 30 until the end of the experiment. At the beginning of phase III, a second phytoplankton bloom developed in mesocosms M2 and M8, sustained from recycled production with a low Chl $a$ concentration $\left(0.7 \mu \mathrm{g} \mathrm{L}^{-1}\right.$ on day 37 , Figure $\left.2 \mathrm{~A}\right)$. Cumulative BPP increased constantly during phase III and bacterial activity remained on a high level during the post-bloom (Figure 2D).

Apart from these general trends, the two mesocosms with the highest $p \mathrm{CO}_{2}$ treatments $\left(1,030\right.$ and $890 \mu$ atm $\left.p \mathrm{CO}_{2}\right)$ showed higher Chl $a$ and DOC concentrations during recycled production in post-bloom phase III. This trend is significant in a linear regression of both, DOC and Chl $a$ with phase-averages of $p \mathrm{CO}_{2}(p<0.05)$ (Supplementary Materials Figure 1$)$. It has to be noted that the plankton community composition in both high $\mathrm{CO}_{2}$ treatments was clearly different from the other treatments and may have accounted for the differences in both, DOC and Chl $a$ (Taucher et al., 2017). There were no differences with $\mathrm{CO}_{2}$ between treatments for phases I and II.

\section{The Succession of Molecular DOM Composition}

Taken together, a total of 7,212 intact compounds with assigned molecular formulae were identified across all mesocosm samples after removal of contaminant signals. For further statistical analysis, the 5,205 molecular formulae with highest signal intensities were selected from each sample. This number was chosen because it was the lowest number in a single sample across the entire sample set. SPE-DOC concentrations in the collected DOM extracts reflect the same general trends as DOC concentration (Figure 2C) and our analysis can thus be considered representative for the fraction in DOM that showed variability during the experiment. FT-ICR-MS signal intensities followed an overall similar pattern with a bell-shaped distribution along the mass axis and an intensity weighted maximum at 372 Da. Using PCA, we could summarize $60 \%$ of the total variability of the complex molecular information in a single component (PC1). This component correlated significantly in a Pearson's product-moment correlation with DOC and showed a highly reproducible trend among all independent mesocosm units over time (Pearson, $r=0.60, p<0.0001, n=79$ ). Thus, it represents the accumulating molecular signature (Supplementary materials Figure 2). A positive correlation was observed for PC3 with $\mathrm{CO}_{2}$ (Pearson, $r=0.20, p<0.05, n=79$ ). This component, however, explains only $6 \%$ of the total observed variability. In agreement to the results from PCA, the dissimilarity on a BrayCurtis level from on average $8.7 \%$ in phase I and phase II, which is within our analytical error, increased to $14.4 \%$ in phase
III (Supplementary materials Figure 3), but without indications for a trend associated to $p \mathrm{CO}_{2}$ levels and the same amount of variability was observed for comparing control to control mesocosms and control to high $\mathrm{CO}_{2}$ mesocosms.

To compare the succession of DOM on a molecular level between individual mesocosm units in more detail, we performed targeted statistical analysis on specific compound groups using cumulative BPP as proxy. We assume that molecular formulae showing close coupling to cumulative BPP in their succession of signal intensities represent the DOM that is a product of bacterial transformation of freshly produced carbon. This fraction of the marine DOM pool accumulates over timescales of weeks to months and is most important in terms of carbon storage. A Pearson correlation of the normalized signal intensities with cumulative BPP for the individual mesocosms revealed that 50\% of all detected molecular formulae $(n=3,583)$ were showing significant correlations with cumulative BPP (Pearson, $p<0.05$ ) (Figure 3). This is in good agreement to the results from BrayCurtis based dissimilarity analysis. No differences were observed

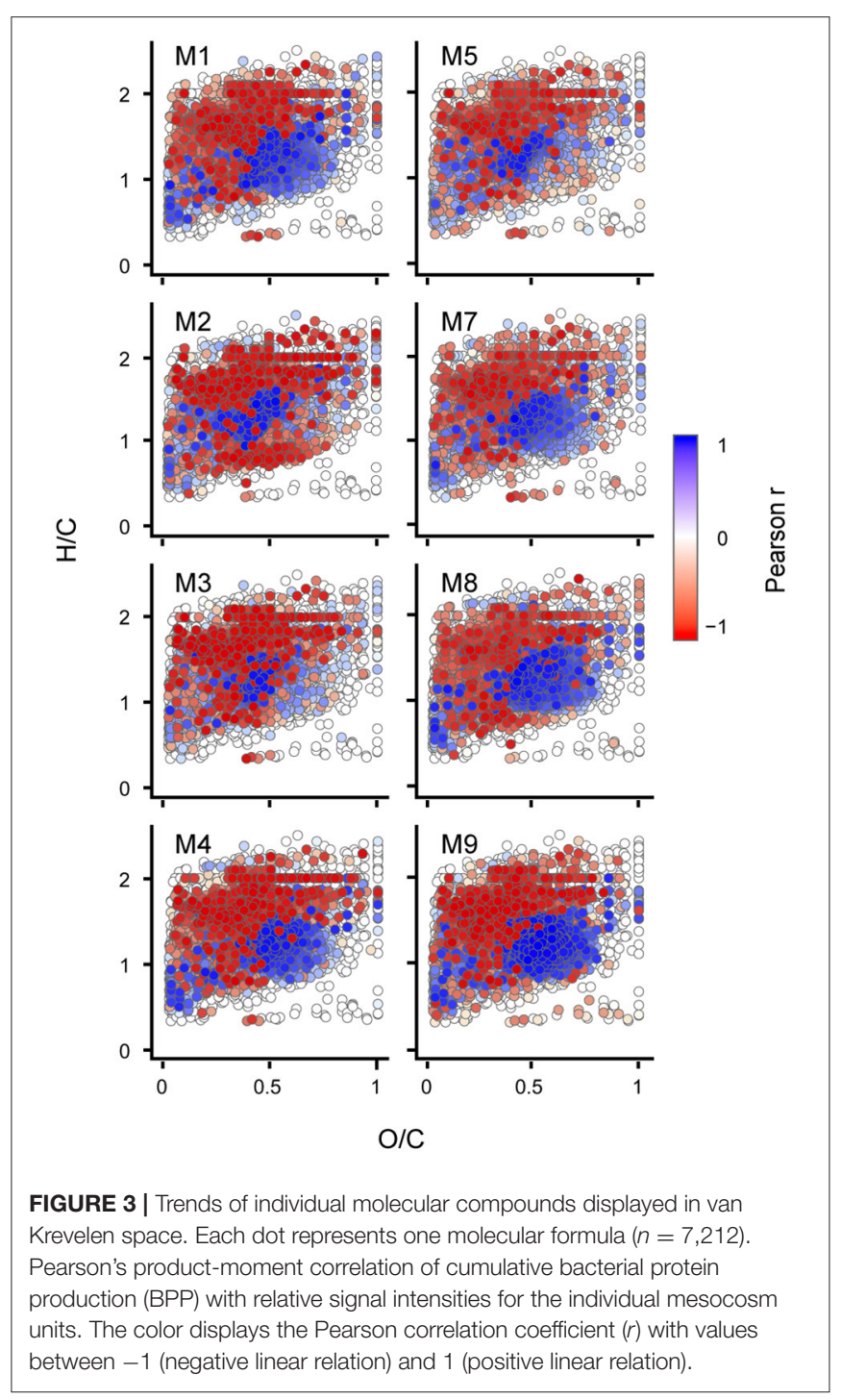


in the type of accumulating molecular formulae between $\mathrm{CO}_{2}$ levels.

To test for generality of these results, we applied the same proxy approach to published molecular DOM data from a mesocosm experiment performed in a eutrophic and temperate environment in the Swedish Gullmar Fjord (Zark et al., 2015a,b). For the fraction of common molecular formulae present in both studies $(n=3,972)$, we searched for molecular formulae showing co-correlation with cumulative BPP (Figure 4C) by calculating Pearson's product-moment correlation coefficients $(r)$ for each individual molecular formula (Figure 4B). In a second step, Pearson's product-moment correlation coefficients between individual mesocosms were calculated to test whether molecular formulae show the same co-correlation patterns in the two experiments contrasting in location and habitat features (Figure 4A). The result was highly significant with average Pearson correlation coefficients of $r=0.71$ for this study and $r=0.68$ for the eutrophic study in the Swedish Fjord (Pearson, $p<0.0001$ ). The average of the Pearson correlation coefficients between both experiments was lower, but also highly significant $(r=0.46, p<0.0001)$. Grouping the molecular formulae into molecular categories confirmed this finding (Figure 5). While aliphatic compounds were not produced over the course of both experiments (Figures 5A,B), highly unsaturated compounds, also known as carboxyl-rich alicyclic molecules (CRAM) (Hertkorn et al., 2006) decreased in relative intensity (Figures 5C,D,E,F). It should be mentioned that these molecular categories are deduced from elemental compositions only, without further structural information (Šantl-Temkiv et al.,
2013). The overall percentages of the individual compound groups varied with trophy, i.e., between the eutrophic and oligotrophic systems (Figure 5). Most importantly, however, there were no major differences in the most abundant compound groups.

\section{DISCUSSION}

\section{$\mathrm{CO}_{2}$ Effects on the Marine DOM Pool}

No differences were observed between the mesocosms during DOC production in phases I and II with respect to bulk parameters and DOM molecular composition. The increase in DOC concentration in phase I was presumably caused by several factors. In the beginning of phase I a bloom of unicellular picocyanobacteria occurred, followed by a dust event from day 16 to day 22 which induced an increase of diatom biomass (Taucher et al., 2017). Concentrations of DOC and SPE-DOC started to diverge between treatments with the onset of recycled production in phase III, after inorganic nutrients added by the deep water injection had been consumed. DOC concentrations were highest in the two mesocosms with highest $p \mathrm{CO}_{2}(890$ and $1,030 \mu \mathrm{atm})$ during this period. This is likely an indirect effect of differences in plankton community structure, which were induced by elevated $p \mathrm{CO}_{2}$ and remained apparent in all three phases of the experiment (Taucher et al., 2017). Our findings provide evidence for the existence of a threshold for indirect $p \mathrm{CO}_{2}$-effects on DOC concentrations above $\sim 890 \mu \mathrm{atm}$ $p \mathrm{CO}_{2}$. Doubtlessly, this estimate is very coarse considering the chosen $\mathrm{pCO}_{2}$ levels, spatial limitations of the mesocosms, the

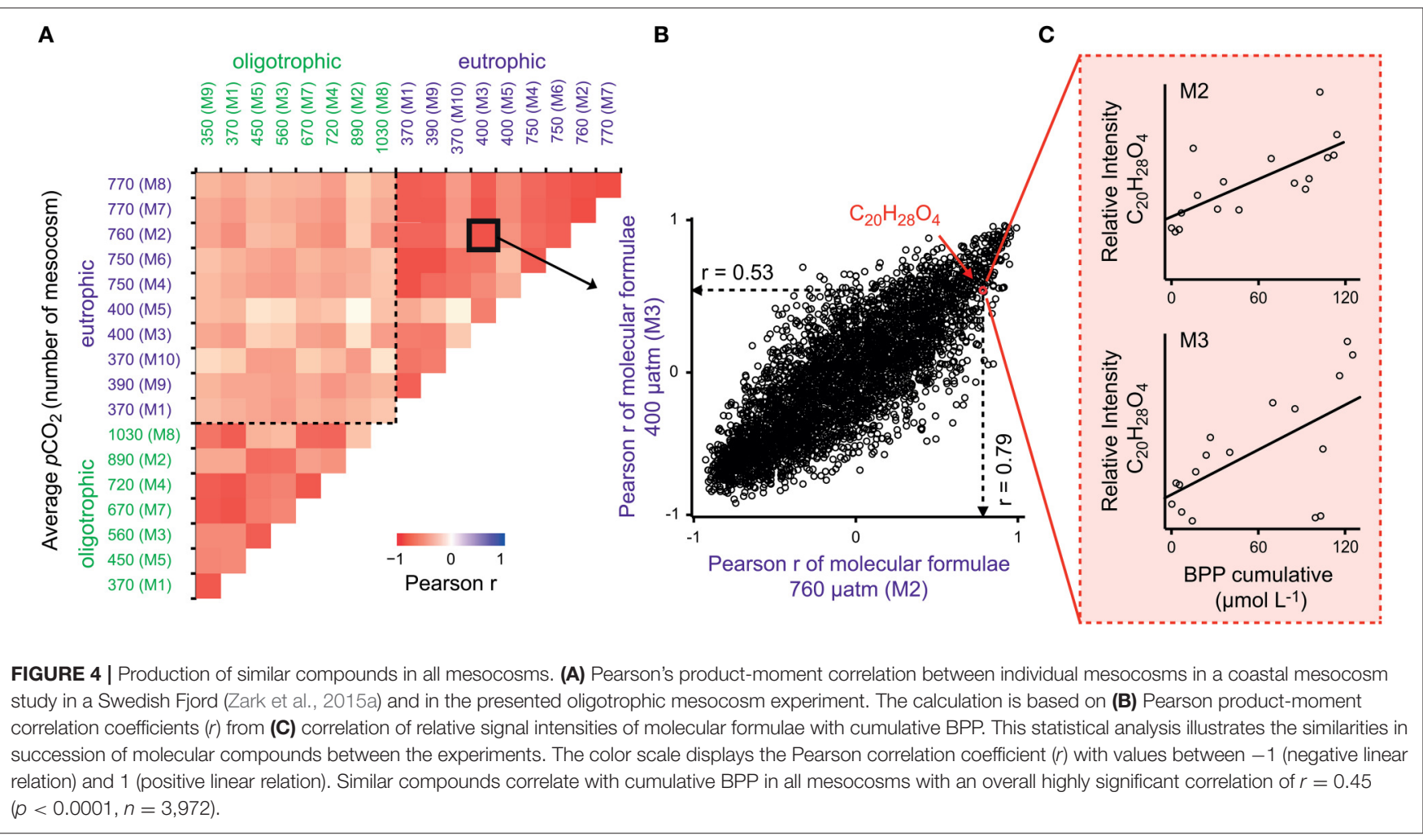




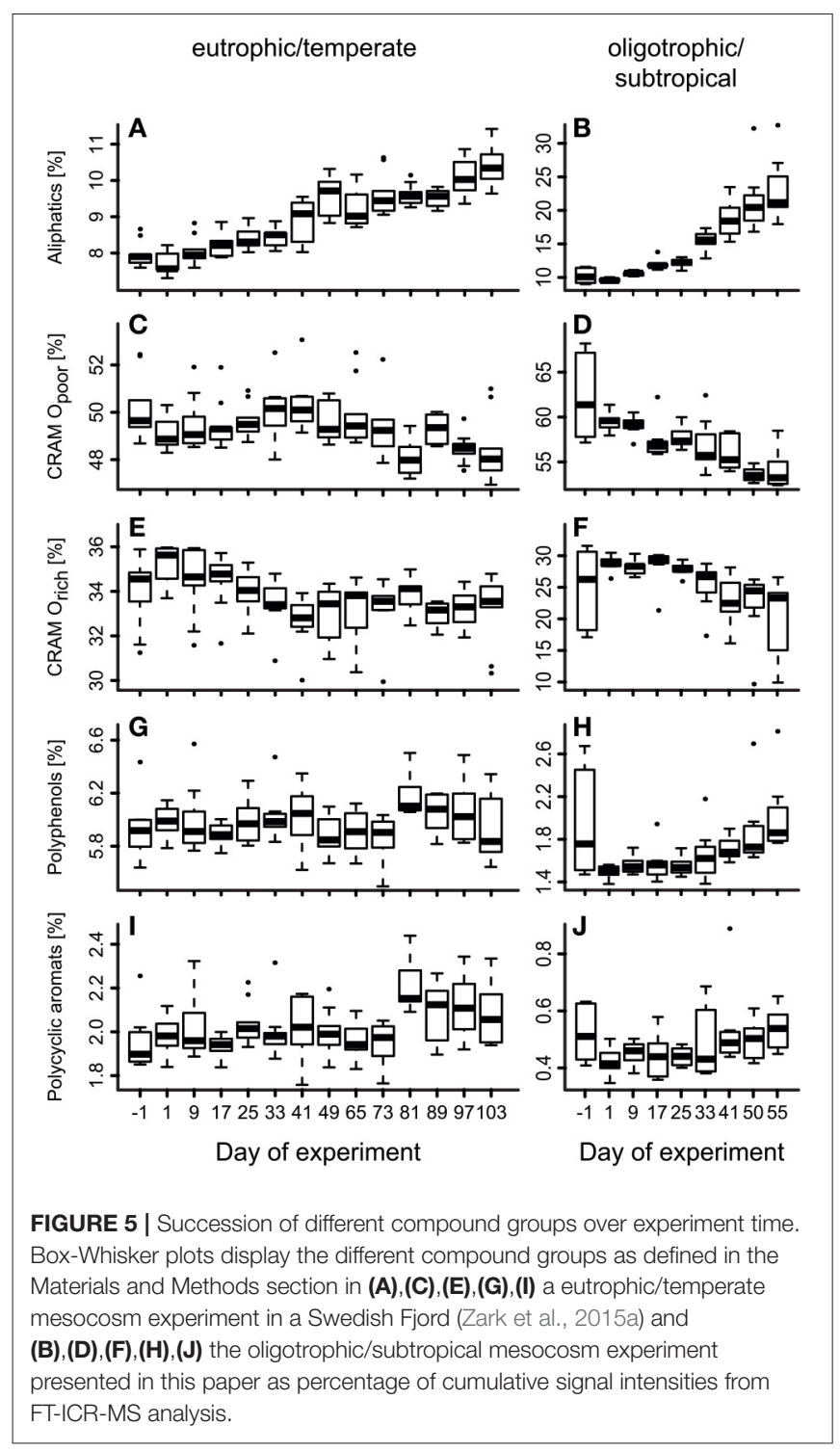

lack of replicates, and the fact that only a short time period was monitored compared to the time scales typically used for projections. Nevertheless, they are consistent with previous mesocosm experiments, for example with studies conducted in Finland (Paul et al., 2015) and in the Arctic (Czerny et al., 2013; Engel et al., 2013) where higher DOC accumulation was observed under strongly elevated $p \mathrm{CO}_{2}$ levels of up to $1,420 \mu \mathrm{atm}$. In agreement to the proposed threshold, it was reported that lower maximum target levels of $\sim 700-800 \mu \mathrm{atm} \mathrm{pCO}_{2}$ showed no significant effect on DOC concentration (MacGilchrist et al., 2014; Zark et al., 2015a). These studies, however, were all conducted in coastal areas under eutrophic conditions. Studies conducted under oligotrophic conditions in the Mediterranean Sea without artificial addition of nutrients showed no effect on chlorophyll $a$ and DOC accumulation under higher $p \mathrm{CO}_{2}$ levels of up to $\sim 1,000 \mu$ atm (Maugendre et al., 2017). Incubation studies using water from the oligotrophic Okhotsk Sea even show higher DOC removal under enhanced $\mathrm{CO}_{2}$ (Yoshimura et al., 2010). Conclusively, the effect of $p \mathrm{CO}_{2}$ on DOM quantity appears to be ambiguous in the literature, most likely because it may strongly depend on the environmental settings, particularly the respective location, nutritional status and organismic community composition.

\section{Production of a Fraction of Compounds with Similar Molecular Formulae in All Mesocosms}

In a previous mesocosm experiment in a Swedish Fjord with elevated $\mathrm{pCO}_{2}$ levels of $760 \mu \mathrm{atm}$, we observed no effects of $p \mathrm{CO}_{2}$ on DOM compounds being consumed or produced over time (Zark et al., 2015a; Bach et al., 2016). The same was true for this study in the subtropical North Atlantic Ocean. Despite indications for DOC accumulation, the overall effect of $p \mathrm{CO}_{2}$ on DOM bulk molecular composition, if present, is smaller than the variance between control replicates toward the end of the experiment. Nevertheless, it is possible that some DOM compounds are produced by phytoplankton and quickly recycled by bacteria as a response to elevated $\mathrm{CO}_{2}$ levels. Such enhanced cycle would not necessarily leave detectable imprints in the DOM molecular composition of our samples, because our sampling frequency did not resolve the relevant time scales and possibly also because of rapid aggregation of biopolymers to particles (Engel et al., 2004, 2014; Taucher et al., 2015). Furthermore, $\mathrm{CO}_{2}$ may have a strong impact on specific DOM degradation processes which become not apparent in bulk analyses (Allgaier et al., 2008; Bergen et al., 2016).

To improve our current understanding of the underlying DOM dynamics, cumulative BPP was used as proxy to assess in more detail the $\mathrm{pCO}_{2}$-induced differences in the accumulating DOM fraction over time. It is important to differentiate between DOM reactivity fractions because DOM with short turnover times does not significantly contribute to oceanic carbon export, unless it aggregates to larger particles which sink to the bottom and get buried in the sediment. On the other hand, longerlived DOM compounds may contribute to carbon sequestration into the oceans interior. Due to the sampling frequency and duration, we covered mainly two operationally-defined reactivity fractions of DOM in our study, i.e., labile and semi-labile DOM. A major fate of photosynthetically produced labile DOM is quick turnover within the microbial loop on timescales of hours to days (Ducklow et al., 2001; Hansell, 2013), whereas semi-labile DOM resists microbial degradation in the surface ocean and accumulates over months and years before it is transported to depths of $>100 \mathrm{~m}$ (Hansell et al., 2012). We assumed that semi-labile DOM compounds accumulate as a result of bacterial activity and thus correlate with cumulative BPP. It has to be noted, that other cumulative data may be also used as proxy for the accumulating DOM, but may not be environmentally meaningful. Refractory and ultra-refractory DOM may also have been produced by microbial transformation or other processes during our study, but cannot be separated from semi-labile DOM, since the lifetime of both reactivity fractions exceeds by far the duration of our experiment. However, it should be noted that 
due to our sampling frequency (every second day) highly labile DOM was not resolved as well.

We found that half of the detected molecular formulae showed significant $(p<0.05)$ correlation with cumulative BPP similar for all mesocosms over time. This finding is remarkable, given the fact that the plankton community composition inside the mesocosms differed in relation to the $p \mathrm{CO}_{2}$ level (Taucher et al., 2017). Whereas, freshly produced DOM from different phytoplankton species is clearly distinct in its individual chemical composition (Landa et al., 2014), the accumulating DOM fraction in our experiment, which remains after an initially rapid remineralization and microbial degradation of the highly labile compounds, was not. This notion may be explained by functional redundancy either in plankton communities regarding production of similarly stable compounds, or in degradation processes. Our results from a natural system support previous small-scale mesocosm experiments indicating production of similar compounds over long timescales despite variability in phytoplankton composition (Osterholz et al., 2015).

Applying the same approach to the molecular DOM data from our experiment in a Swedish Fjord (Zark et al., 2015a,b), we found a similar fraction of molecular formulae in both, the oligotrophic North Atlantic Ocean and the eutrophic fjord system. In both experiments, they significantly correlated with cumulative BPP in a similar manner. These findings suggest that compounds with the same elemental composition also show the same spatial and temporal dynamics in production and degradation. The formation of similar molecular compounds following the breakdown of the phytoplankton bloom, independent of environmental conditions such as phytoplankton community structure and acidification, indicates a rather universal microbial DOM transformation in different ecosystems. This finding points toward a high resilience of processes shaping the molecular DOM signature in complex pelagic communities.

\section{CONCLUSION}

DOM concentration and composition in our large-scale mesocosm experiments showed the same succession independent of $p \mathrm{CO}_{2}$ treatment. OA induced effects became only apparent at the two highest $\mathrm{CO}_{2}$, i.e., levels $>890 \mu$ atm, through elevated DOC concentrations during the last experimental phase. However, molecular DOM pool composition remained the same. Regarding climate scenarios, the obtained $\mathrm{pCO}_{2}$ threshold level will be reached under the "business as usual emission" scenario until the end of the century (IPCC, 2014; Gattuso et al., 2015). However, the observed trends were not pronounced and can only serve as an indicator. If excess DOC was available in a future high $\mathrm{CO}_{2}$ ocean, it could function as nutrient for new production. Alternatively, it could be sequestered and may thereby cause a negative feedback to the climate system. $p \mathrm{CO}_{2}$ levels below $\sim 890 \mu \mathrm{atm}$ did not reveal significant differences in DOM quality and molecular compound groups show similar dynamics over the succession of phytoplankton blooms in two highly contrasting environments, i.e., a temperate eutrophic vs. a subtropical oligotrophic system. This finding indicates a high resilience of microbial DOM transformation processes independent of any environmental variable leading to generally very similar temporal dynamics of DOM groups following phytoplankton blooms. Comparing different large-scale OA mesocosm experiments, thus, provides valuable insights into the biogeochemical dynamics of DOM compounds.

\section{AUTHOR CONTRIBUTIONS}

All authors were involved in conceiving the study. MZ, UR, TH, and NB took the samples. MZ and NB conducted solid-phase extractions. FT-ICR-MS analysis was performed by MZ. TH and HG analyzed BPP rates. Statistical analyses were done by MZ and TD. MZ wrote the manuscript with comments from all other authors.

\section{FUNDING}

Financial support for this study was provided by the German Ministry of Education and Research (BMBF, FKZ 03F06550 and FKZ 03F07280) through the BIOACID (Biological Impacts of Ocean ACIDification) project. UR received additional funding from the Leibniz Award 2012 by the German Research Foundation (DFG).

\section{ACKNOWLEDGMENTS}

We thank the team of the Gran Canaria mesocosm experiment in 2014, in particular A. Ludwig for the logistical organization and coordination. We also thank the staff of the Plataforma Oceánica de Canarias (PLOCAN) for hosting our team, sharing their research facilities, and providing technical assistance. We thank the captain and crew of RV Hesperides for deploying and recovering the mesocosms (cruise 29HE20140924) and RV Poseidon for transporting the mesocosms and providing support in testing the deep water collector during cruise POS463. The authors furthermore thank K. Klaproth, M. Friebe, and I. Ulber for technical support with FT-ICR-MS and DOC/TDN analysis. We acknowledge A. Nauendorf for the analysis of Chl $a$ concentrations, J. Meyer for carbonate chemistry measurements, and Eliesabeth Walter for support of BPP measurements. Nutrient concentrations were kindly provided by E. Achterberg and M. Esposito. All DOM data is archived at the PANGAEA data library (pangaea.de/10.1594/PANGAEA.869453) and will be made available upon request.

\section{SUPPLEMENTARY MATERIAL}

The Supplementary Material for this article can be found online at: http://journal.frontiersin.org/article/10.3389/fmars. 2017.00271/full\#supplementary-material 


\section{REFERENCES}

Allgaier, M., Vogt, M., Thyrhaug, R., Riebesell, U., and Grossart, H.-P. (2008). Coupling of heterotrophic bacteria to phytoplankton bloom development at different $\mathrm{pCO}_{2}$ levels: a mesocosm study. Biogeosciences 5, 317-359. doi: $10.5194 /$ bg-5-1007-2008

Aristeguí, J., Barton, E. D., Álvarez-Salgado, X. A., Santos, A. M. P., Figueiras, F. G., Kifani, S., et al. (2009). Sub-regional ecosystem variability in the Canary Current upwelling. Prog. Oceanogr. 83, 33-48. doi: 10.1016/j.pocean.2009.07.031

Azam, F., Fenchel, T., Field, J. G., Gray, J. S., Meyer-Reil, L. A., and Thingstad, F. (1983). The ecological role of water-column microbes in the sea. Mar. Ecol. Prog. Ser. 10, 257-263. doi: 10.3354/meps010257

Bach, L. T., Taucher, J., Boxhammer, T., Ludwig, A., The Kristineberg, KOSMOS Consortium, Achterberg, E. P., et al. (2016). Influence of ocean acidification on a natural winter-to-summer plankton succession: first insights from a longterm mesocosm study draw attention to periods of low nutrient concentrations. PLoS ONE 11:e0159068. doi: 10.1371/journal.pone.0159068

Bergen, B., Endres, S., Engel, A., Zark, M., Dittmar, T., Sommer, U., et al. (2016). Acidification and warming affect prominent bacteria in two seasonal phytoplankton blooms. Environ. Microbiol. 18, 4579-4595. doi: 10.1111/1462-2920.13549

Bray, J. R., and Curtis, J. T. (1957). An ordination of the upland forest communities of Southern Wisconsin. Ecol. Monogr. 27, 325-349. doi: 10.2307/1942268

Carlson, C. A., Del Giorgio, P. A., and Herndl, G. J. (2007). Microbes and the dissipation of energy and respiration: from cells to ecosystems. Oceanography 20, 89-100. doi: 10.5670/oceanog.2007.52

Czerny, J., Schulz, K. G., Boxhammer, T., Bellerby, R. G. J., Büdenbender, J., Engel, A., et al. (2013). Implications of elevated $\mathrm{CO}_{2}$ on pelagic carbon fluxes in an Arctic mesocosm study - an elemental mass balance approach. Biogeosciences 10, 3109-3125. doi: 10.5194/bg-10-3109-2013

Dickson, A. G., Afghan, J. D., and Anderson, G. C. (2003). Reference materials for oceanic $\mathrm{CO}_{2}$ analysis: a method for the certification of total alkalinity. Mar. Chem. 80, 185-197. doi: 10.1016/S0304-4203(02)00133-0

Dittmar, T., Koch, B., Hertkorn, N., and Kattner, G. (2008). A simple and efficient method for the solid-phase extraction of dissolved organic matter (SPE-DOM) from seawater. Limnol. Oceanogr. Methods 6, 230-235. doi: $10.4319 / \mathrm{lom} .2008 .6 .230$

Ducklow, H. W., Steinberg, D. K., and Buesseler, K. O. (2001). Upper ocean carbon export and the biological pump. Oceanography 14, 50-58. doi: 10.5670/oceanog.2001.06

Dutkiewicz, S., Morris, J. J., Follows, M. J., Scott, J., Levitan, O., Dyhrman, S. T., et al. (2015). Impact of ocean acidification on the structure of future phytoplankton communities. Nat. Clim. Change 5, 1002-1006. doi: $10.1038 /$ nclimate 2722

Eberlein, T., Wohlrab, S., Rost, B., John, U., Bach, L. T., Riebesell, U., et al. (2017). Effects of ocean acidification on primary production in a coastal North Sea phytoplankton community. PLoS ONE 12:e0172594. doi: 10.1371/journal.pone.0172594

Engel, A., Borchard, C., Piontek, J., Schulz, K. G., Riebesell, U., and Bellerby, R. (2013). $\mathrm{CO}_{2}$ increases ${ }^{14} \mathrm{C}$ primary production in an Arctic plankton community. Biogeosciences 10, 1291-1308. doi: 10.5194/bg-10-1291-2013

Engel, A., Piontek, J., Grossart, H.-P., Riebesell, U., Schulz, K. G., and Sperling, M. (2014). Impact of $\mathrm{CO}_{2}$ enrichment on organic matter dynamics during nutrient induced coastal phytoplankton blooms. J. Plankton Res. 36, 641-657. doi: $10.1093 /$ plankt/fbt125

Engel, A., Thoms, S., Riebesell, U., Rochelle-Newall, E., and Zondervan, I. (2004). Polysaccharide aggregation: a sink of marine dissolved organic carbon. Nature 428, 929-932. doi: 10.1038/nature02453

Gattuso, J.-P., Magnan, A., Billé, R., Cheung, W. W. L., Howes, E. L., Joos, F., et al. (2015). Contrasting futures for ocean and society from different anthropogenic $\mathrm{CO}_{2}$ emissions scenarios. Science 349 , aac4722. doi: $10.1126 /$ science.aac 4722

Green, N. W., Perdue, E. M., Aiken, G. R., Butler, K. D., Chen, H., Dittmar, T., et al. (2014). An intercomparison of three methods for the large-scale isolation of oceanic dissolved organic matter. Mar. Chem. 161, 14-19. doi: 10.1016/j.marchem.2014.01.012

Grossart, H.-P., Allgaier, M., Passow, U., and Riebesell, U. (2006). Testing the effect of $\mathrm{CO}_{2}$ concentration on the dynamics of marine heterotrophic bacterioplankton. Limnol. Oceanogr. 51, 1-11. doi: 10.4319/lo.2006.51. 1.0001

Hansell, D. A. (2013). Recalcitrant dissolved organic carbon fractions. Annu. Rev. Mar. Sci. 5, 421-445. doi: 10.1146/annurev-marine-120710-100757

Hansell, D. A., Carlson, C. A., and Schlitzer, R. (2012). Net removal of major marine dissolved organic carbon fractions in the subsurface ocean. Global Biogeochem. Cycles 26:GB1016. doi: 10.1029/2011GB004069

Hedges, J. I. (1992). Global biogeochemical cycles: progress and problems. Mar. Chem. 39, 67-93. doi: 10.1016/0304-4203(92)90096-S

Hertkorn, N., Benner, R., Frommberger, M., Schmitt-Kopplin, P., Witt, M., Kaiser, K., et al. (2006). Characterization of a major refractory component of marine dissolved organic matter. Geochim. Cosmochim. Acta 70, 2990-3010. doi: 10.1016/j.gca.2006.03.021

Hofmann, G. E., Smith, J. E., Johnson, K. S., Send, U., Levin, L. A., et al. (2011), High-frequency dynamics of ocean $\mathrm{pH}$ : a multi-ecosystem comparison. PLoS ONE 6:e28983. doi: 10.1371/journal.pone,.0028983

IPCC (2014). "Climate Change 2014: impacts, adaptation, and vulnerability. Part A: global and sectoral aspects," in Contribution of Working Group II to the Fifth Assessment Report of the Intergovernmental Panel on Climate Change (Cambridge; New York, NY: Cambridge University Press).

Joint, I., Doney, S. C., and Karl, D. M. (2011). Will ocean acidification affect marine microbes? ISME J. 5, 1-7. doi: 10.1038/ismej.2010.79

Kirchman, D. L. (1993). "Leucine incorporation as a measure of biomass production by heterotrophic bacteria," in Handbook of Methods in Aquatic Microbial Ecology, eds P. F. Kemp, B. F. Sherr, E. B. Sherr, and J. J. Cole (Boca Raton, FL: Lewis), 509-512.

Koch, B. P., and Dittmar, T. (2006). From mass to structure: an aromaticity index for high-resolution mass data of natural organic matter. Rapid Commun. Mass Spectrom. 20, 926-932. doi: 10.1002/rcm.2386

Koch, B. P., Dittmar, T., Witt, M., and Kattner, G. (2007). Fundamentals of molecular formula assignment to ultrahigh resolution mass data of natural organic matter. Anal. Chem. 79, 1758-1763. doi: 10.1021/ac061949s

Kroeker, K. J., Kordas, R. L., Crim, R. N., and Singh, G. G. (2010). Meta-analysis reveals negative yet variable effects of ocean acidification on marine organisms. Ecol. Lett. 13, 1419-1434. doi: 10.1111/j.1461-0248.2010.01518.x

Landa, M., Cottrell, M. T., Kirchman, D. L., Kaiser, K., Medeiros, P M., Tremblay, L., et al. (2014). Phylogenetic and structural response of heterotrophic bacteria to dissolved organic matter of different chemical composition in a continuous culture study. Environ. Microbiol. 16, 1668-1681. doi: 10.1111/1462-2920.12242

Le Queré, C., Peters, G. P., Andres, R. J., Andrew, R. M., Boden, T., and Ciais, P. (2013). Global carbon budget 2013. Earth Syst. Sci. Data 6, 689-760. doi: 10.5194/essdd-6-689-2013

Longhurst, A., Sathyendranath, S., Platt, T., and Caverhill, C. (1995). An estimate of global primary production in the ocean from satellite radiometer data. J. Plankt. Res. 17, 1245-1271. doi: 10.1093/plankt/17.6.1245

Lueker, T. J., Dickson, A. G., and Keeling, C. D. (2000). Ocean $\mathrm{pCO}_{2}$ calculated from dissolved inorganic carbon, alkalinity, and equations for $\mathrm{K} 1$ and $\mathrm{K} 2$ : validation based on laboratory measurements of $\mathrm{CO}_{2}$ in gas and seawater at equilibrium. Mar. Chem. 70, 105-119. doi: 10.1016/S0304-4203(00)00022-0

MacGilchrist, G. A., Shi, T., Tyrell, T., Richier, S., Moore, C. M., Dumousseaud, C., et al. (2014). Effects of enhanced $\mathrm{pCO}_{2}$ levels on the production of dissolved organic carbon and transparent exopolymer particles in short-term bioassay experiments. Biogeosciences 11, 3695-3706. doi: 10.5194/bg-11-3695-2014

Maugendre, L., Gattuso, J.-P., Poulton, A. J., Dellisanti, W., Gaubert, M., Guieu, C., et al. (2017). No detectable effect of ocean acidification on plankton metabolism in the NW oligotrophic Mediterranean Sea: results from two mesocosm studies. Estuar. Coast. Shelf Sci. 186, 89-99. doi: 10.1016/j.ecss.2015.03.009

Mopper, K., Stubbins, A., Ritchie, J. D., Bialk, H. M., and Hatcher, P. G. (2007). Advanced instrumental approaches for characterization of marine dissolved organic matter: extraction techniques, mass spectrometry, and nuclear magnetic resonance. Chem. Rev. 107, 419-442. doi: 10.1021/ cr050359b

Moran, M. A., Kujawinski, E. B., Stubbins, A., Fatland, R., Aluwihare, L. I., Buchan, A., et al. (2016). Deciphering ocean carbon in a changing world. Proc. Natl. Acad. Sci. U.S.A. 113, 3143-3151. doi: 10.1073/pnas.1514645113

Neuer, S., Cianca, A., Helmke, P., Freudenthal, T., Davenport, R., Meggers, H., et al. (2007). Biogeochemistry and hydrography in the eastern subtropical North 
Atlantic gyre. Results from the European time-series station ESTOC. Prog. Oceanogr. 72, 1-29. doi: 10.1016/j.pocean.2006.08.001

Oksanen, J., Blanchet, F. G., Kindt, R., Legendre, P., Minchin, P. R., O'Hara, R. B., et al. (2013). Vegan: Community Ecology Package. R package version 2.0-10. Available online at: http://CRAN.R-project.org/package=vegan

Osterholz, H., Niggemann, J., Giebel, H.-A., Simon, M., and Dittmar, T. (2015). Inefficient microbial production of refractory dissolved organic matter in the ocean. Nat. Commun. 6, 7422. doi: 10.1038/ncomms 8422

Paul, A. J., Bach, L. T., Schulz, K.-G., Boxhammer, T., Czerny, J., Achterberg, E. P., et al. (2015). Effect of elevated $\mathrm{CO}_{2}$ on organic matter pools and fluxes in a summer Baltic Sea plankton community. Biogeosciences 12, 6181-6203. doi: 10.5194/bg-12-6181-2015

Pierrot, D. E., Lewis, E., and Wallace, D. W. R. (2006). MS Excel Program Developed for $\mathrm{CO}_{2}$ System Calculations. ORNL/CDIAC-105a, Carbon Dioxide Information Analysis Center, Oak Ridge National Laboratory, U.S. Department of Energy, Oak Ridge, TN.

Piontek, J., Lunau, M., Händel, N., Borchard, C., Wurst, M., and Engel, A. (2010). Acidification increases microbial polysaccharide degradation in the ocean. Biogeosciences 7, 1615-1624. doi: 10.5194/bg-7-1615-2010

Qian, J., and Mopper, K. (1996). Automated high-performance, high-temperature combustion total organic carbon analyzer. Anal. Chem. 68, 3090-3097. doi: $10.1021 /$ ac $960370 \mathrm{z}$

Riebesell, U. (2000). Carbon fix for a diatom. Nature 407, 959-960. doi: $10.1038 / 35039665$

Riebesell, U., Bach, L. T., Bellerby, R. G. J., Bermúdez Monsalve, J. R., Boxhammer, T., Czerny, J., et al. (2017). Competitive fitness of a predominant pelagic calcifier impaired by ocean acidification. Nat Geosci. 10, 19-23. doi: 10.1038/ngeo 2854

Riebesell, U., Czerny, J., von Bröckel, K., Boxhammer, T., Büdenbender, J., Deckelnick, M., et al. (2013). Technical note: a mobile sea-going mesocosm system - new opportunities for ocean change research. Biogeosciences 10, 1835-1847. doi: 10.5194/bg-10-1835-2013

Riebesell, U., Schulz, K. G., Bellerby, R. G. J., Botros, M., Fritsche, P., Meyerhöfer, M., et al. (2007). Enhanced biological carbon consumption in a high $\mathrm{CO}_{2}$ ocean. Nature 450, 545-549. doi: 10.1038/nature06267

Riedel, T., and Dittmar, T. (2014). A method detection limit for the analysis of natural organic matter via Fourier transform ion cyclotron resonance mass spectrometry. Anal. Chem. 86, 8876-8382. doi: 10.1021/ac501946m

Riedel, T., Zark, M., Vähätalo, A. V., Niggemann, J., Spencer, R. G. M., Hernes, P. J., et al. (2016). Molecular signatures of biogeochemical transformations in dissolved organic matter from ten world rivers. Front. Earth Sci. 4:85. doi: $10.3389 /$ feart.2016.00085

Romera-Castillo, C., Letscher, R. T., and Hansell, D. A. (2016). New nutrients exert fundamental control on dissolved organic carbon accumulation in the surface Atlantic Ocean. Proc. Natl. Acad. Sci. U.S.A. 113, 10497-10502. doi: 10.1073/pnas.1605344113

Rossel, P. E., Vähätalo, A. V., Witt, M., and Dittmar, T. (2013). Molecular composition of dissolved organic matter from a wetland plant (Juncus effusus) after photochemical and microbial decomposition ( $1.25 \mathrm{yr})$ : common features with deep sea dissolved organic matter. Org. Geochem. 60, 62-71. doi: 10.1016/j.orggeochem.2013.04.013
Salisbury, J., Green, M., Hunt, C., and Campbell, J. (2008). Coastal acidification by rivers: a threat to shellfish? Eos 89, 513. doi: 10.1029/2008EO500001

Šantl-Temkiv, T., Finster, K., Dittmar, T., Hansen, B. M., Thyrhaug, R., and Nielsen, N. W. (2013). Hailstones: a window into the microbial and chemical inventory of a storm cloud. PLoS ONE 8:e53550. doi: 10.1371/journal.pone.0053550

Schulz, K. G., Bellerby, R. G. J., Brussaard, C. P. D., Büdenbender, J., Czerny, J., Engel, A., et al. (2013). Temporal biomass dynamics of an Arctic plankton bloom in response to increasing levels of atmospheric carbon dioxide. Biogeosciences 10, 161-180. doi: 10.5194/bg-10-161-2013

Simon, M., and Azam, F. (1989). Protein content and protein synthesis rates of planktonic marine bacteria. Mar. Ecol. Prog. Ser. 51, 201-213. doi: 10.3354/meps051201

Stubbins, A., and Dittmar, T. (2012). Low volume quantification of dissolved organic carbon and dissolved nitrogen. Limnol. Oceanogr. Methods 10, $347-$ 352. doi: 10.4319/lom.2012.10.347

Taucher, J., Bach, L. T., Boxhammer, T., Achterberg, E. P., Algueró-Muñiz, M., Arístegui, J., et al. (2017). Influence of ocean acidification and deep water upwelling on oligotrophic plankton communities in the subtropical North Atlantic: insights from an in situ mesocosm study. Front. Earth. Sci. 4:85. doi: 10.3389/fmars.2017.00085

Taucher, J., Jones, J., James, A., Brzezinski, M. A., Carlson, C. A., Riebesell, U., et al. (2015). Combined effects of $\mathrm{CO}_{2}$ and temperature on carbon uptake and partitioning by the marine diatoms Thalassiosira weissflogii and Dactyliosolen fragilissimus. Limnol. Oceanogr. 60, 901-919. doi: 10.1002/lno.10063

Yoshimura, T., Nishioka, J., Suzuki, K., Hattori, H., Kiyosawa, H., and Watanabe, Y. W. (2010). Impacts of elevated $\mathrm{CO}_{2}$ on organic carbon dynamics in nutrient depleted Okhotsk Sea surface waters. J. Exp. Mar. Biol. Ecol. 395, 191-198. doi: $10.1016 /$ j.jembe.2010.09.001

Zark, M., Riebesell, U., and Dittmar, T. (2015a). Effects of ocean acidification on marine dissolved organic matter are not detectable over the succession of phytoplankton blooms. Sci. Adv. 1:e1500531. doi: 10.1126/sciadv. 1500531

Zark, M., Riebesell, U., and Dittmar, T. (2015b). Dissolved organic matter molecular composition and concentrations from a large scale mesocosm study KOSMOS 2013 Kristineberg) on ocean acidification. PANGAEA. doi: 10.1594/PANGAEA.846137

Zhai, W., and Zhao, H. (2016). Quantifying air-sea re-equilibration-implied ocean surface $\mathrm{CO}_{2}$ accumulation against recent atmospheric $\mathrm{CO}_{2}$ rise. J. Oceanogr. 72, 651. doi: $10.1007 /$ s10872-016-0350-8

Conflict of Interest Statement: The authors declare that the research was conducted in the absence of any commercial or financial relationships that could be construed as a potential conflict of interest.

Copyright (๑) 2017 Zark, Broda, Hornick, Grossart, Riebesell and Dittmar. This is an open-access article distributed under the terms of the Creative Commons Attribution License (CC BY). The use, distribution or reproduction in other forums is permitted, provided the original author(s) or licensor are credited and that the original publication in this journal is cited, in accordance with accepted academic practice. No use, distribution or reproduction is permitted which does not comply with these terms. 